\title{
Using the work of Beck to Analyse Indonesian Student Activists and Forms of Risk
}

\author{
Pam Nilan, Gregorius R. Wibawanto
}

University of Newcastle | Universitas Gadjah Mada

pamela.nilan@newcastle.edu.au | gregorius.rw@gmail.com

\section{ABSTRACT}

Dengan menggunakan konsepsi Ulrich Beck mengenai risiko, artikel ini mengkaji cara pandang mahasiswa aktivis pro-lingkungan hidup di jurusan Teknik Lingkungan, Institut Teknologi Bandung (ITB). Temuan kami menunjukan bahwa meskipun mereka merasa memiliki tanggungjawab moral untuk melestarikan alam dan mengambil sikap terhadap persoalan lingkungan hidup yang dihadapi oleh masyarakat marginal -secara epistemologis - mereka masih terbawa oleh prinsip teknokratik dalam memandang jurusan Teknik Lingkungan. Terlebih dengan pertimbangan akan kesuksesan hidup yang akan mereka harapi setelah lulus kuliah. Oleh karena itu, di samping simpati mendalam pada gagasan pro-lingkungan hidup, mereka tetap tertarik untuk menjalani karir yang menjanjikan dalam industri pertambangan global yang beroperasi di Indonesia. Berkaitan dengan hal ini, kami berpendapat bahwa sebagai pemuda dengan kecenderungan mobilitas sosial vertikal - yang hidup di dalam konteks modernitas lanjut - mereka harus menegosiasikan risiko personal dan risiko kerusakan lingkungan hidup secara global bersamaan dengan proses menegosiasikan peluang hidup di masa depan.

KEYWORDS Pemuda Indonesia | Environmentalisme | Risiko | Beck

\section{PREFACE}

Ulrich Beck (1992) argues that in late modernity we live in a 'risk' society. Risks are not just local or national, but global and even digital. For example, the circulation of 'fake' news on social media is a risk in itself. Youth today must negotiate unprecedented risks as they negotiate the precarious labour market (Standing 2011), even if they come from the middle class. Upwardly mobile young Indonesians, like youth everywhere, are a generational cohort confronting new historical circumstances (see Mannheim 1952). They encounter diverse circumstances of risk driven by new national and global forms of capital accumulation, distribution and movement. Beck (1992:20) recommends recognizing new patterns of 'distribution' in late modernity. The time-honoured logic of wealth distribution has changed to a new logic of risk distribution. In new circumstances, risks have been distributed into various institutions: family, university, the labour market, even the field of activism itself. Young Indonesians today must negotiate with, and navigate around, all those different kinds of redistributed risks.

This article looks at how six young Indonesian activists about to graduate from the environmental engineering degree at ITB in 2015 were dealing with different levels of risk, calling on Beck's (1992) original definition of risk. They experienced an ethical dilemma because they were environmental engineers in the making, yet they were also environmental 
activists at the same time. As activists, they were well aware of environmental risks. Yet they were reluctant to put a likely prosperous future at risk. As high-achieving middle class students they wanted to satisfy their parents' investment in their university study at ITB. The most predictable career for them was to become environmental engineers in the mining industry. However, mining activities are responsible for much environmental destruction in Indonesia. They feared putting their environmental principles at risk by seeking that kind of job. They imagined other career possibilities which would allow their continued identity as environmental activists.

The findings reported in this article generate some new knowledge about contemporary young people and environmentalism. We know that many young people in the world today are greatly concerned about degradation of the natural environment and the effects of climate change (Jia et al 2015; Boeve-de Pauw and Van Petegem 2010). Universities are places where youth environmental activism readily takes place (Nomura and Suyono 2014; Weiss, Aspinall and Thompson 2012; Schultz, Simpson and Elfessi 2011; Wray-Lake, Flanagan and Osgood 2010). Environmental 'hope' seems to have risen among youth almost everywhere (Ojala 2012). Although some have argued that the environmental awareness of Indonesian students is low (Parker 2018; Kusmawan et al 2009), other studies indicate increasing levels of environmental awareness among Indonesian young people (Koch et al 2013; Crosby 2013; Alam, Nilan and Leahy 2018).

Is environmental engineering environmentally informed?

In practice, there is not much that is 'environmental' about a university degree in environmental engineering. In fact, environmental engineering 'remains within the purview of standard engineering protocol' (Allen, Giampetro and Little 2003:391). Environmental engineers primarily create 'control systems to minimize adverse effects' (Reible 2017:3) - on humans. Risks to plant and animal species, and even the biosphere itself, are not in that purview. Arguably, environmental engineers are as much in danger of creating risk as alleviating it. For example, in extraction industries like mining, environmental engineers are responsible for arranging 'compliance' with the government's environmental protection laws. However, those laws are often not respected (see Robinson and Erb 2017; Mietzner 2015). Indonesia has extensive mineral reserves and huge profits are there to be made.

The massive scale of mineral, oil and gas extraction in Indonesia means that companies like Freeport, Newmont, Chevron (all US) and Vale (Brazil) - and their subsidiaries - are keen to recruit Indonesian environmental engineering graduates who will push mining development forward by preparing environmental impact statements and developing post-extraction remediation plans. Yet that is not an ethically reassuring future option for an idealistic young environmental activist. Mining is one of the highest risk industries for environmental impact (Gedicks 2015). Young Indonesian environmental activists do not want to become part of the problem. 'Indonesia has [long] been extracting natural resources at the expense of the ecological wellbeing of future generations' (Kurniawan and Managi 2018:2; also Cribb 2003). We know the ecological crisis "has socially destabilizing long-term effects that can scarcely be overestimated' (Beck 1995:8). For example, some Indonesian rivers are now the most polluted in the world (Tarahita and Rakhmat 2018), posing great risk to human life. Unfortunately, corruption is rife (Mietzner 2015) in regulation of the Indonesian resources sector. Political patronage safeguards the interests and profits of private companies. Accounts may be 'greenwashed', and critical reports may be buried (Purnomo et al. 2017:8). These are potential pitfalls in the career scenario that young environmental engineers face when Jurnal Studi Pemuda 8(2), 2019 wrwer.jurnal.ugm.ac.idljurnalpemuda 
they graduate. The ITB activists were looking for alternative ways to successfully negotiate income and activism.

We propose that in their final semester of study they were creating what Beck (1992) called an 'epistemological fallacy'. They imagined that they could create a high-income career in the field of environmental engineering, yet continue to work at saving and protecting the environment at the same time. In their final semester in 2015 they were living on the edge of that epistemological 'contradiction' (France and Haddon 2014), with risk on every side. Let us summarize their dilemma. The informants for this study knew very well the risks from climate change, weather catastrophes, pollution and the like (see Beck et al. 2013). Yet they also felt the future livelihoods and wellbeing of their families were at risk if they did not translate their environmental engineering degree into a solid income. These two kinds of risks - global and personal - are coercively connected in Beck's terms (2011). It can be argued that when a young person chooses a neoliberal future that guarantees material wealth, they simultaneously engage risk at the global level. The prosperous middle-class lifestyle requires high consumerism and thereby increases the intensity of environmental problems in the world, as Naomi Klein (2014) argues. Beck (1992) identified the paradox of simultaneous progress and risk. In brief, as economic growth drives progress, environmental risks expand exponentially. So, if these young Indonesian university activists capitalize on their environmental engineering degree and take the high salaries on offer from transnational mining companies, then they will be profiting economically at the expense of the natural environment which they would like to protect.

\section{METHODOLOGY}

The data here comes from a large-scale study of environmentalism and education in
Indonesia. As a component of that project, interviews with students involved in environmental activism were conducted on selected campuses in Java and Sumatra: UGM, UI, ITB, UNPAD, UNSRI. The interview data analysed below was collected at Institut Teknologi Bandung (ITB) in 2015. Six of the young activists interviewed at ITB were both environmental engineering students and committed environmental activists at the same time. In no other campus sample did we find that cluster of an environmental engineering degree challenged by pro-environmental activism. We decided to undertake in-depth analysis of those six interviews because their expressed dilemmas exemplify tension between environmental risk and risk to personal status and income. That tension goes to the heart of current environmental challenges for Indonesia as a nation. It also closely reflects Beck's (1992) argument about the paradoxical co-existence of progress and risk in late modernity. For the six interview transcripts, a chronological thematic analysis was developed through coding informant responses to key interview questions about the history of their activism, current campus and off-campus environmental activism, and their future plans to protect the natural environment.

The table below summarizes the six informants, including an indication of early activism that featured in their journey towards the current activist position they now occupy at university. The table also shows their responses to the question about the most significant global environmental problems in the world today, and their career ambitions. The table below summarizes the six informants, including an indication of early activism that featured in their journey towards the current activist position they now occupy at university. The table also shows their responses to the question about the most significant global environmental problems in the world today, and their career ambitions.

ANALYSIS 


\begin{tabular}{|c|c|c|c|c|}
\hline Name & $\begin{array}{c}\text { Early activism } \\
\text { (before university) }\end{array}$ & Degree Major & $\begin{array}{l}\text { Named environmental prob- } \\
\operatorname{lem}(s) \text { in world }\end{array}$ & Career ambition \\
\hline $\begin{array}{c}\mathrm{Aziz} \\
(\mathrm{m}, 20)\end{array}$ & $\begin{array}{l}\text { Challenged local dumping } \\
\text { of domestic waste }\end{array}$ & $\begin{array}{l}\text { Solid waste } \\
\text { (trash) }\end{array}$ & $\begin{array}{l}\text { Global warming, air pollution, excess } \\
\text { garbage }\end{array}$ & $\begin{array}{l}\text { Take on a political leadership role after } \\
\text { studying abroad }\end{array}$ \\
\hline $\begin{array}{l}\text { Rosita } \\
(f, 21)\end{array}$ & $\begin{array}{l}\text { Campaigned against litter- } \\
\text { ing in national parks }\end{array}$ & $\begin{array}{l}\text { Solid waste } \\
\text { (trash) }\end{array}$ & $\begin{array}{l}\text { Global warming, rising sea level, air } \\
\text { pollution, excess garbage }\end{array}$ & $\begin{array}{l}\text { Work for a mining company committed } \\
\text { to environmental improvement }\end{array}$ \\
\hline $\begin{array}{l}\text { Agung } \\
(\mathrm{f}, 21)\end{array}$ & $\begin{array}{l}\text { Removed trash from } \\
\text { waterways; prevented } \\
\text { flooding }\end{array}$ & $\begin{array}{l}\text { Solid waste } \\
\text { (sanitation) }\end{array}$ & Garbage, water pollution & $\begin{array}{l}\text { Become an environmental engineering } \\
\text { consultant }\end{array}$ \\
\hline $\begin{array}{c}\text { Doni } \\
(\mathrm{m}, 21)\end{array}$ & $\begin{array}{l}\text { Anti-Styrofoam campaign } \\
\text { at high school }\end{array}$ & $\begin{array}{l}\text { Solid waste } \\
\text { (trash) }\end{array}$ & $\begin{array}{l}\text { Industrial development encourages } \\
\text { 'throw-away' consumerism; causes } \\
\text { extensive pollution of waterways }\end{array}$ & $\begin{array}{l}\text { Work for an NGO, or a company } \\
\text { engaged in the right way with the envi- } \\
\text { ronment, or as a consultant }\end{array}$ \\
\hline $\begin{array}{l}\text { Raihana } \\
\text { (f, 21) }\end{array}$ & $\begin{array}{l}\text { Represented Indonesia on } \\
\text { the international stage of } \\
\text { climate activism }\end{array}$ & $\begin{array}{l}\text { Water } \\
\text { (systems) }\end{array}$ & Climate change, clean water & $\begin{array}{l}\text { Work in the Ministry of the Envi- } \\
\text { ronment as a civil servant; represent } \\
\text { Indonesia at the United Nations }\end{array}$ \\
\hline $\begin{array}{l}\text { Tiara } \\
(f, 21)\end{array}$ & $\begin{array}{l}\text { Campaigned to reduce } \\
\text { plastic in school cafeteria, } \\
\text { and for clean oceans }\end{array}$ & $\begin{array}{l}\text { Water } \\
\text { (sanitation) }\end{array}$ & $\begin{array}{l}\text { Global warming, clean water, sanita- } \\
\text { tion, waste processing }\end{array}$ & $\begin{array}{l}\text { Become Minister for the Environment } \\
\text { or work for an environmental NGO }\end{array}$ \\
\hline
\end{tabular}

\section{Pathways to Ecological Awareness}

We know from the relevant literature that the environmental identities of young people form primarily from early experience (Chawla 2006; Matsuba and Pratt 2013); Mifsud 2012; Kollmuss and Agyeman 2002); Prévot, Clayton and Mathevet 2018). So, what were the journeys of the six ITB informants to the point of environmental awareness? The following brief profiles give a sense of how early experience of risk propelled development of their environmental consciousness.

Aziz showed an early talent for mathematics when he was at school. In senior high school he was advised to study civil engineering. Aziz is a devout Muslim. He prayed fervently for guidance in his future life path. He came to the realization that since childhood he had hated the great stinking piles of household waste that polluted the area around his family home. So, he decided that he would indeed choose to study engineering, but in the specialization of environmental engineering. Aziz explained how he made the decision, 'there are families who throw away litter, and I always scolded them. From that experience I came to consider environmental engi neering. He enrolled at ITB and eventually found an ideal mentor. "In the third year [of this degree] I found a professor who is an expert on waste. I've been crazy happy' (Aziz, m, 20, 31 January 2015, Secretariat HMTL). Aziz was started on his journey to environmental awareness by a tangible negative experience; the polluting impact of dumped domestic waste. His final year community service project was to generate energy from recycled local solid waste.

Rosita said that her eyes were opened to environmental crisis when she undertook a science class field trip to Gunung Gede Pangrango National Park when she was in high school. The purpose of the field visit was 'to observe and research the state of the environment there' (Rosita, f, 21, 1 February 2015, Secretariat HTML). She said she was greatly moved by the natural beauty of the park, yet horrified by the extensive littering and waste pollution from domestic tourism. She made a vow to herself that she would take action to protect the natural landscape. To achieve that she joined junior WWF (World Wide Fund for Nature) Indonesia, which is a branch of the transnational WWF organization. Rosita kept up her membership of WWF when she went to university. She also became a member of a local NGO, the Bandung Green Community. 
Furthermore, she had been a regular attendee at discussions organized by the regional branch of WALHI (Wahana Lingkungan Hidup Indonesia - Indonesian Forum for the Environment). WALHI was first founded as an environmental organization in 1980. It is the largest and most influential environmental advocacy NGO in Indonesia and gives direct advice to government. Rosita's community service activity was to develop systems for recycling solid waste.

Agung's sense of environmental risk was developed early in life when she experienced the terrifying inundation, evacuation and ruin of her family home in Semarang, a coastal town prone to extensive flooding. She was only a little girl when that disaster happened. She came to understand later that frequent extensive flooding in Semarang was not a 'natural' event, but resulted from poor urban development planning and inadequate domestic waste disposal that blocked water drainage flows. That memorable experience opened her awareness of the need to respect and protect the natural environment. Agung had chosen the environmental engineering degree at ITB in Bandung because she thought that by working as an environmental engineer she might assist in the prevention of such disasters. Her final year community service project was to devise a system for removing discarded domestic waste from waterways.

Doni had been active in raising environmental awareness even while he was still at junior high school. For example, he and his friends pioneered a campaign against the use of Styrofoam in the school cafeteria. Later he joined Pecinta Alam (Nature Lovers Club) in senior high school and enthusiastically undertook group trekking in wild places, where he was astounded by the beauty of the landscape. Those deep experiences in nature inspired him to take action to conserve the natural environment. He said, 'I thought then of going into environmental engineering. I'm here because I want to see a cleaner nature' (Doni, m, 21, 2 February
2015, Secretariat HMTL). He was highly active in environmental campaigns and student politics across campus.

Raihana was still in high school when she made an entrance on the international stage of climate change activism. She was sponsored to attend an international Climate Change conference, 'I was selected from SMA North Sumatra to attend the conference in Mexico. There we learned about the Kyoto protocol' (Raihana, f, 21, 4 February 2015, Siete Café). That event put her on the political map for environmental activism and she was subsequently selected to attend the Climate Reality Project Asia Pacific Summit in Jakarta. At the Summit she met one of the world's most significant environmentalists. 'The event was attended by Al Gore as a speaker, it was him who taught me how to be a presenter'. Her international profile as a 'green' youth ambassador did not stop there however. 'Subsequently I attended the Qatar conference'. All that happened for Raihana before the age of 20. In senior high school she showed a talent for mathematics and was advised to enroll in civil engineering. However, she had other ideas. 'I got to know about the Climate Reality Project, and that actually concerns climate change (...) I was thinking about the environment really a lot, so in the end I enrolled in environmental engineering'. She was pleased with the content of the environmental engineering degree at ITB. 'I get to learn about waste water, garbage, and pollution, so it really fits'. Raihana's final year community service project was to design a sustainably functioning toilet block for a poor community that had previous used the nearby river for their needs.

Tiara had long been a scuba diving enthusiast. Her environmentalism developed from encounters with the natural world under the sea. It was very beautiful, but often polluted. Her concerns brought her into contact with ocean environmentalists. 'I love scuba diving and so from the start I became close to the environmentalist community' (Tiara, f, 21, 6 February 2015, Secretariat HMTL). 
She had been taking an activist role since junior high school. For example, she and her friends had campaigned to reduce the use of plastic in the school cafeteria. A high achiever in mathematics, she said she chose the environmental engineering degree because of its potential, "my thinking was that it [environmental engineering] is a cool science if you can use it properly'. Tiara's chosen major was in water and her key community service activity in the final year included political organizing for environmental change on campus.

It is evident that all six informants had strong pro-environmental roots built on earlier life experiences. Their excellent academic performance in MIPA subjects at senior high school meant that they were able to enroll in a prestigious degree at ITB. Engineering had been recommended by their schools. Each of them had then chosen the environmental engineering degree because it appeared to dovetail with their environmentalist concerns. However, the standard engineering content of the environmental engineering degree at ITB invited them to view environmental issues mainly through a technocratic lens, which rather set their socially critical views to one side. To understand that technocratic focus, it will be instructive to look at their involvement in the student organization HMTL, which sets out to offer practical training experiences to complement the classroom learning in the degree.

\section{HMTL: Keeping it real}

The ITB Environmental Engineering Student Association - HMTL (Himpunan Mahasiswa Teknik Lingkungan) organizes community service projects where the students can apply the technical engineering skills they learn in the formal syllabus of the degree. All of them thought HMTL offered excellent practical learning projects, '[HMTL] can be preparation for work. I get to see reality and I can't get it if I just listen in class' (Agung, f, 21, 1 February 2015, Secretariat HMTL).
The six informants had all joined HMTL in the first semester of their degree. They were working on community service projects organized by HMTL. Yet at the same time, they were using the resources of HMTL to conduct environmental activism on campus that reflected their idealism. Like many similar jurusan-based clubs at ITB, HMTL members had elected to combat littering on campus. Some had even created regular working groups to clear nearby waterways. Campaigns of that kind on university campuses reflect the fact that waste is such a major problem for Indonesia,

Between 15 and 40 percent of waste is not getting collected at all. As a result, much ends up in uncontrolled dump sites, leading to leachates that contaminate groundwater and contributing to the proliferation of disease-carrying pests (Dethier 2017:75).

Nevertheless, the core business of HMTL was to offer industry and government-sponsored projects to environmental engineering students. The strong message was that technological solutions could solve any environmental problem caused by industry and mining. There is no doubt that the informants had absorbed the ideology of that technocratic principle, for example, one informant reassured the interviewer that,

Human habitation can be located in the hinterland of industry. As long as the industrial waste is processed and disposed of properly there will be no negative impact and those communities will be healthy (Rosita).

Moreover, Rosita believed that contacts and networking gained through HMTL would help her get a job; 'the seniors there greatly inspired me. Lots more, lots more links. For example, I got to know more alumni because we so often associate with them'. It is common in Indonesia for young people to find out about jobs from friends, older kin and alumni (Kuzubas and Szabo 2013). Of course, many of the 'seniors' she refers to had found jobs in the mining industry, because that is the main career destination for ITB environmental engineering graduates. 
Aziz was actively involved in HMTL. He said he always encouraged critical thinking among members. He believed that 'practitioners and stakeholders' hold the key to solving waste problems through effective system design, 'infrastructure is a problem, and so is lack of public awareness. But what is really broken is the system'. He had pioneered a partner village program through HMTL to build infrastructure for generating energy directly from household waste that would eventually generate profits for poor communities. There is already a 'local waste economy in Indonesia linked to broader systems of production and consumption' (Schlehe and Yulianto 2018:5) but it is piecemeal and unreliable. Aziz's proposed solution was to standardize the system itself. We may note that this approach means viewing waste primarily as a (rebranded) 'resource'. In principle, that challenges the Indonesian legislative goal of reducing waste because more waste means more energy can be generated and more profits can be made. That particular conundrum matches Beck's point about the 'boomerang' nature of environmental risk, where a hazard is implicitly amplified by a 'solution' that relies on the technocratic underpinnings of modernisation itself (Beck 1992:21). In fact, Aziz' role model was the technocrat ex-President B.J. Habibie, 'look at Habibie for example, he made the point that if the transport industry was advanced, Indonesia would gain much more respect internationally, and our need for imports would be lowered. He had that dream. That's the kind of leader idealism we need'. Aziz was pleased to be developing that kind of technological leadership capacity through his work in HMTL.

In the last semester of his degree Doni had become the chair of HMTL. Fulfilling that role was his primary activity beyond formal study. Doni believed in the potential of HMTL for creating environmental impact. He maintained that environmental organizations act as shields of defence; nurturing the environmental awareness that will enable us to live sustainably in the future. Doni explained how HMTL facilitated his pro-environmental activism.

If you are studying Environmental Engineering then you want to contribute to the environment. I do that. Early on I set the goal of conserving nature on campus. I felt that could surely have a big impact.

From his senior position in HMTL, Doni had directed many environmental awareness campaigns on campus including the introduction of a system of effective waste disposal and teams to clean waterways, as well as 'greening' the campus. However, we noted that Doni was a rarity in HMTL, like the other five activist informants. Their classmates were primarily interested in gaining work experience and industry contacts through HMTL. Overall, the most salient influence of HMTL was to reinforce, through practical experience, the core ideology of the environmental engineering degree; that a technocratic solution can solve any environmental risk.

\section{Work after graduation}

All six informants saw themselves taking a prominent role in the years after graduation. Aziz's ambition was to become a political leader in Indonesia after studying abroad. Rosita saw herself working for a mining company that was committed to environmental improvement. Agung thought she might become an environmental engineering consultant. Doni envisaged working as a consultant, possibly for an environmental NGO. If he did work in industry, he hoped it would be for a company engaged in the 'right way' with the environment. Raihana was firmly committed to the goal of representing Indonesia on matters of the environment at the United Nations. She planned to first work at the Ministry of the Environment as a civil servant so she had sufficient experience. Tiara suggested she could eventually become the Indonesian Minister for the Environment, but in the short term she saw herself working for an environmental NGO. 
Yet in terms of that imagined future after graduation, the informants openly expressed their ambivalence about the personal risks they faced. For example, Aziz identified reluctance to turn his back on the promise of prosperity,

I cannot personally guarantee that I will remain consistent and idealistic after I graduate. It seems that many graduates from Environmental Engineering enter the Oil and Gas industry, and they become financially very secure. Who would not want to get a starting salary of 12 million per month? The overseas Oil and Gas industries give that kind of guarantee (Aziz).

Others drew attention to the risk of disappointing family expectations, for example,

Now [end of degree] we are still idealistic, but not so much. There is so much pressure. Our parents want us to finish quickly; we are trying to get the best grades; building up a work CV so we can easily get a job (...) it's all changing (Tiara).

Tiara implies that the heady days of student environmental idealism will soon be behind them as they confront the high-risk labor market. At this crucial point, her environmental idealism and the field of employment appear to be in direct tension.

Rosita was also keenly aware of the need to achieve financial security; 'the money is the thing'. She told the interviewer enthusiastically, 'recently I was out on work experience [mining company] and I met an older ITB alumnus. And from that meeting I was offered a job'. In negotiating the risk to her ethical position, Rosita envisaged a future scenario in which she held down a mining company job while still being involved in pro-environmental campaigns.

I am certainly aware of that contradiction. I think that if I want to do something in the future to save the environment and I have no capital, then it will be difficult. It would be easier to have money to continue the struggle. I don't mean that I will become a worker in the industry and forget about social aspects. I must remember those aspects. If I get rich later, then I must remind myself (Rosita).
There are layers of risk negotiation implied in Rosita's explanation. At the deepest level, she remains concerned about the environmental problems caused by excess waste and contamination. However, she is tempted by an existing mining job offer with high wages, even while acknowledging the risk of compromising her ideals. She was worried about that choice, and rightly so. In the interview, Rosita talked about the corruption problem in implementing appropriate environmental regulation, 'the government is very inconsistent. All permissions can be lobbied using money'. She told the interviewer she had heard environmental engineers were sometimes bought off, 'an alumnus told me that he once had to make a waste disposal management report that was full of lies because the company had bribed government members'. Notably, Aziz told the interviewer exactly the same story. They saw a clear risk of getting involved in corruption if they went to work for an extractive or resource-based industry. Nevertheless, Rosita implies that she might, after all, take the high-paid job in the mining company. She imagines it might be all right so long as she 'remembers' her environmentalist concerns.

Agung proposed that she could be the major consultant for an 'environmental' enterprise, and earn a good salary at the same time. She argued that, 'it's impossible for us to take care of the environment if we don't have funds' She added, 'we can be experts in the field of sanitation, but we must not close off the possibility of developing it as an energy source. The higher you go the more expertise is needed', implying that there is little point in just having knowledge about sanitation. Relevant to the 'recycle' component of the current Indonesian '3R' legislation, she envisages an NGO that would be responsible for the implementation of a standard waste re-processing system. Agung explained that system in technical terms. Solid human waste would be efficiently processed to become a source of natural gas and hydrogen - an alternative energy supply. However, she knew start-up funds would be required, so she imagined an existing NGO as 
the base for such an enterprise. Agung implied that she would be the paid consultant on such a project. In principle, that job would alleviate the two major risks in her future. She would remain true to her environmental ideals and earn a high salary at the same time.

Doni was beset by a sense of dilemma. He spoke in heartfelt terms about his choices, 'I am really worried now about what I will do after graduation. That's confusing for me (...) I'm sure there must be a way and people who care, and organizations that can make it happen'. He said he feared losing 'the idealism I have for Indonesia'. He reassured the interviewer that he had not lost his love of nature, 'I often engage with the natural world that I care about so much'. Doni told the interviewer that he did want to be like an 'industrialist' who does not feel the impact of waste pollution, while the ordinary people suffer the impact. In short, Doni would like to remain at the level of the common people in ethical terms even as he uses his environmental engineering skills to protect and conserve the natural world. He did not mention the matter of career income.

Raihana acknowledged that her choice to work for the government went against the grain of a typical environmental engineering career. She recounted that, "people put me down, you know, why not just work in the oil and gas industry (...) Civil servants are so, so, so - you know. Government bureaucracy is very bad, you know everything like that. What the hell are you doing? Yet I would like to do that. I want to work for Indonesia'. She told the interviewer that her family did not understand her choice. Her parents were not civil servants, she said. They thought working for the government would be 'hard' and like 'career suicide'. They reminded her that she was a high achiever in 'hard' science, not social science, so she had not been trained in civil service skills. Nevertheless, she was adamant about what she would NOT be doing after she graduated, 'I have never, ever considered working in the Oil and Gas industry'
Raihana knew she was idealistic but refuted the idea that her commitment to combating climate change made her seem awkward or unfashionable. She was sure of her ethical position, 'I can be a really cool person and still want to work for the benefit of others, and not think about money'.

Tiara had high environmentalist ideals which she was determined to preserve after graduation. Nevertheless, her industry internship placement had been with a mining company. She defended that experience,

Oops well, I only went to Freeport just for work practice. And now I'm just about to do that again. Why? Because as my dad said, if you want to change something, you have to change it from the inside, from inside the system. If you don't do that then it won't happen (...) as far as the future is concerned, at least I have experience working in the mining industry due to my work experience with Freeport. So if I do end up working in an NGO, then I will be able to tell them so much about the mining industry (...) even if there is not much money in it, at least I will make life better for my grandchildren. Seriously, I am not profit oriented (Tiara).

From these brief insights into their career expectations and choices after graduation, we can see that all informants were experiencing a sense of contradiction. In summary, they enjoyed a reputation as environmental activists at ITB, having chosen environmental engineering primarily from a love of, and concern for, nature, as well as a desire to improve the lives of poor people. They were highly active members of HMTL, participating in both community service programs and on-campus 'greening' campaigns. Yet at the end of their degrees they faced compelling questions about the personal and global risks of a future environmental engineering career.

\section{DISCUSSION}

Epistemological risks to the pro-environmentalist idealism of these young activists are 
amply revealed in the analysis of interview data above. First, through the environmental engineering and HMTL community projects the young people have become accomplished problem-solvers, and see the world as a series of technological challenges to be solved by their professional knowledge. Second, their ITB-accredited engineering degree lets them know that they should make a successful career in the mining industry. Yet, third, they are ethically-committed environmentalists with extensive knowledge about environmental risks. In brief, they want to use their skills, please their parents, maintain (improve) their social and economic status, and all at the same time, continue their important work as environmental activists. It was evident that they were reluctant to work for destructive and less-than-accountable transnational mining companies, yet they were tempted by high incomes that matched their privileged graduate status.

The dilemma they face generates an 'epistemological fallacy' (Beck 1992; Furlong and Cartmel 2007; France and Haddon 2014). They know what they know through the technocratic lens of environmental engineering. Yet they also have a stake in the global episteme of environmentalism; reducing consumption and waste and conserving nature for future generations. They want to believe they can gain a career, wealth and status while working to save the natural environment and protecting vulnerable people. We know that they are part of the 'global generation' of contemporary youth who are invited to believe that everything is possible at once (see Beck and Beck-Gernsheim 2009). Their sense of dilemma stems from the contradictions of their situation. Today they are environmental activists, tomorrow they risk becoming part of the problem against which they have fought. They must negotiate the personal risk of failing to live up to parental and societal expectations along with managing the global risks faced by the planet. They have sympathy for poor people who suffer from negative environmental impacts. They do not want to lapse into apathy, to become workers who are just concerned with the heft of their pay packet. In that sense the data above aptly highlights how contemporary youth struggle with different kinds of risk in their everyday lives (see Beck and Beck-Gernsheim 2009), including not just economic risks, but also cultural, social and ethical risks to their sense of self and worth. We can also see the personal difficulties in campaigning against large scale environmental risk in a resource-rich developing country like Indonesia.

As Beck (2011) argued, in the end we cannot divorce personal risk from global risk. They are indeed coercively connected. We do not know whether the pro-environmental idealism of these young activists will survive. Yet they were far from blind to the contradictions. They are young people in late modernity. It is possible that, as Beck and Beck-Gernsheim (2002:22-23) claim, they have become accustomed to "constantly changing between different, partly incompatible logics of action'. They are engaged in the navigation of short-term decisions with indeterminate outcomes, trying to work strategically (yet ethically) through largely unknowable circumstances that are greatly inflected by the local and global forms of capital accumulation, distribution and movement. They are dissatisfied with Indonesian government inaction on environmental protection and remediation. Yet at the same time they are high achieving students at a prestigious university. They have internalized the ideology of competitive meritocracy. At no stage did any of them directly question the content of the degree. Rather, they are imbricated in the discourse of success; of pleasing their parents; of earning a high income commensurate with their graduate status, of receiving due recognition and reward for their skills; and so on. They believe that their pro-environmental idealism can co-exist with all that. However, at best, it seems most likely that in future careers they will practice contingent pro-environmental tactics within what Beck (1992) 
has called the logic of human exceptionalism.

\section{GONGLUSION}

Like other well-educated young people of their generation, worldwide, these six young Indonesians are in a position of privilege, yet even the prestigious environmental engineering degree from ITB is not a guarantee of certainty. There seems to be an ontologically certain future waiting for them in the mining industry, but most of them do not want to seek jobs there because of their ethical objection to the environmental destruction and corruption that are synonymous with mining company practice in Indonesia. We may view the personal dilemmas presented here in wider terms, as a public issue for Indonesia. Environmental challenges for the nation lie in the gap between the regulatory mechanisms of the state and the free reign unofficially given to non-state actors, especially transnational private enterprises. That disconnection in the name of profit works to discourage integrated governance solutions (engineering or otherwise) to the numerous environmental crises faced by the nation. By that token, these young Indonesians cannot be blamed for the conditions of risk in which they find themselves reaching for ethically defensible career options. Their pro-environmental activism is laudable in a nation where it is rarely found. In the end, their personal dilemmas point directly to Indonesia's struggle to bring rampant environmental destruction by industry under effective regulation while, at the same time, achieving economic growth.

\section{Acknowledgements}

The large multisite project on environmentalism and education was funded by the Australian Research Council [DP130100051].

\section{REFERENCES}

Alam, Meredian, Pam Nilan and Terry Leahy. 2019. "Learning from Greenpeace: Activist Habitus in a Local Struggle." Electronic Green Journal 1(42):1-18.

Allen, Timothy, Mario Giampetro, and Amanda Little. 2003. "Distinguishing Ecological Engineering from Environmental Engineering." Ecological Engineering 20:389-407.

Beck, Ulrich. 1992. Risk Society: Towards a New Society. London: Sage.

Beck, Ulrich. 1995. Ecological Enlightenment: Essays on the Politics of the Risk Society. London: Humanities Press.

Beck, Ulrich. 2011. "Cosmopolitanism as Imagined Communities of Global Risk." American Behavioral Scientist 55:1346-1361.

Beck, Ulrich, Anders Blok, David Tyfield, and Joy Zhang. 2013. "Cosmopolitan Communities of Climate Risk: Conceptual and Empirical Suggestions for a New Research Agenda." Global Networks 13:1-21.

Beck, Ulrich, and Elisabeth Beck-Gernsheim. 2002. Individualization: Institutionalized Individualism and its Social and Political Consequences. London: Sage.

Beck, Ulrich, and Elisabeth Beck-Gernsheim. 2009. "Global Generations and the Trap of Methodological Nationalism for a Cosmopolitan Turn in the Sociology of Youth and Generation." European Sociological Review 25:25-36.

Boeve de Pauw, Jelle and Peter Van Petegem. 2010. "A Cross-National Perspective on Youth Environmental Attitudes," Environmentalist 30(2):133-44.

Chawla, Louise. 2006. "Research Methods to Investigate Significant Life Experiences: Review and Recommendations." Environmental Education Research 12:359-374.

Cribb, Robert. 2003. "Environmentalism in Indonesian Politics" pp. 37-48 in Adrian Bedner and Nicole Niessen eds. Towards Integrated Environmental Law in Indonesia. Leiden: CWNS Publications. 
Crosby, Amanda. 2013. "Remixing Environmentalism in Blora, Central Java 2005-10." International Journal of Cultural Studies 16(3):25769.

Dethier, Jean-Jacques. 2017. "Trash, Cities, and Politics: Urban Environmental Problems in Indonesia." Indonesia 103:73-90.

France, Alan, and Edward Haddon. 2014. "Exploring the Epistemological Fallacy: Subjectivity and Class in the Lives of Young People." Young 22:305-321.

Furlong, Andy, and Fred Cartmel. 2007. Young People and Social Change: New Perspectives. Maidenhead: Oxford University Press.

Gedicks, Al. 2015. "Transnational Mining Corporations, the Environment, and Indigenous Communities." Brown Journal of World Affairs 22:129-152.

Jia, Fanli, Susan Alisat, Kendall Soucie and $\mathrm{Mi}^{-}$ chael Pratt. 2015. "Generative Concern and Environmentalism: A Mixed Methods Longitudinal Study of Emerging and Young Adults." Emerging Adulthood 3(5):306-319.

Klein, Naomi. 2014. This Changes Everything: Capitalism vs the Climate. New York: Simon \& Schuster.

Koch, Sebastian, Jan Barkmann, Micha Strack, Leti Sundawati and Suzanne Bögeholz. 2013. "Knowledge of Indonesian University Students on the Sustainable Management of Natural Resources." Sustainability 5:1443-60.

Kollmuss, Anya, and Julian Agyeman. 2002. "Mind the Gap: Why do People Act Environmentally and What are the Barriers to Pro-environmental Behavior?" Environmental Education Research 8:239-260.

Kurniawan, Robi, and Shunsuke Managi. 2018. "Economic Growth and Sustainable Development in Indonesia: An Assessment." Bulletin of Indonesian Economic Studies 54:339-361.
Kusmawan, Udan, Mitch O’Toole, Ruth Reynolds and Sid Bourke. 2009. "Beliefs, Attitudes, Intentions and Locality: The Impact of Different Teaching Approaches on the Ecological Affinity of Indonesian Secondary School Stu dents". International Research in Geographical and Environmental Education 18(3):157-169.

Kuzubas, Tolga, and Andrea Szabo. 2013. "Multiple Job Search Networks: Theory and Evidence from Indonesia." Working Papers 2013/06, Bogazici University, Department of Economics. Retrieved August 4, 2018 (https:// pdfs.semanticscholar.org/de $33 / 6 \mathrm{c} 8$ cecb $9 \mathrm{~d}$ 15c60d6b7896ffla63d311a0b74.pdf)

Mannheim, Karl. 1952. "The Problem of Generations" pp. 276-322 in Karl Mannheim Essays on the Sociology of Knowledge. New York: Routledge \& Kegan Paul.

Matsuba, M. Kyle, and Michael Pratt. 2013. "The Making of an Environmental Activist: A Developmental Psychological Perspective" pp. 59-74. In: M. Kyle Matsuba, Pamela King, and Kendall Bronk eds. Exemplar Methods and Research: Strategies for Investigation. New Directions for Child and Adolescent Development. New York: Wiley.

Mifsud, Mark. 2012. "A Meta-analysis of Global Youth Environmental Knowledge, Attitude and Behavior Studies." US-China Education Review, 4: 259-277.

Mietzner, Marcus. 2015. "Dysfunction by Design: Political Finance and Corruption in Indonesia." Critical Asian Studies 47: 587-610.

Nomura, Koh and Eko Agus Suyono. 2014. "The Environment, Sustainability and Universities in Indonesia: An Examination of the Nexus" pp. 159-174. In: John Chi-Kin Lee and Rob Efird eds. Schooling for Sustainable Development across the Pacific. Dordrecht: Springer. 
Prévot, Anne-Caroline, Susan Clayton, and Raphael Mathevet. 2018. "The Relationship of Childhood Upbringing and University Degree Program to Environmental Identity: Experience in Nature Matters." Environmental Education Research 24: 263-279.

Purnomo, Herry, Bayuni Shantiko, Suaduon Sitorus, Harris Gunawan, Ramadhani Achdiawan, Hariadi Kartodihardjo, and Ade Ayu Dewayani. 2017. "Fire Economy and Actor Network of Forest and Land Fires in Indonesia." Forest Policy and Economics 78:21-31.

Reible, Danny. 2017. Fundamentals of Environmental Engineering. New York: Lewis Publishers.

Robinson, Kathryn, and Maribeth Erb. 2017. "Mining - Who Benefits?" Inside Indonesia 130. Online. Retrieved August 4, 2018 (http://www.insideindonesia.org/mining-who-benefits)

Schlehe, Judith, and Vissia Ita Yulianto. 2018. "Waste, Worldviews and Morality at the South Coast of Java: An Anthropological Approach." Occasional Paper No. 41. University of Freiburg Occasional Paper Series. Retrieved August 9, 2018 (www.southeastasianstudies. uni-freiburg.de).
Standing, Guy. 2011. The Precariat. London: Bloomsbury.

Tarahita, Dikanaya, and Muhammad Zulfikar Rakhmat. 2018. "Indonesia's Citarum: The World's Most Polluted River." The Diplomat April 28, 2018. Retrieved August 10, 2018 (https://thediplomat.com/2018/04/indonesias-citarum-the-worlds-most-polluted-river/)

Weiss, Meredith, Edward Aspinall and Mark Thompson. 2012. "Introduction: Understanding Student Activism in Asia" pp. 1-32. In: M. Weiss and E. Aspinall (eds) Student Activism in Asia: Between Protest and Powerlessness. Minneapolis MN: University of Minnesota Press.

Wray-Lake, Laura, Constance Flanagan and D. Wayne Osgood. 2010. "Examining Trends in Adolescent Environmental Attitudes, Beliefs and Behaviors across Three Decades," Environmental Behavior 42(1):61-85. 